\title{
Adolescents' knowledge of oral health: a population-based study
}

\section{Conhecimento do adolescente em relação a saúde bucal: um estudo de base populacional}

\begin{abstract}
Purpose: To evaluate the knowledge on oral health of 10-19 year-old adolescents from the city of Campina Grande, PB, in the Northeast region of Brazil.

Methods: A cross-sectional study was conducted with a random sample of 679 adolescents attending public schools in Campina Grande, PB, Brazil. Data were collected using a semistructured questionnaire and analyzed with Chi-square and Fischer's exact tests.

Results: Most information received by the participants concerned dental diseases $(81 \%$, $P=0.026)$, and the dentist $(66 \%, P=0.475)$ was the most frequently cited source. Approximately half of the subjects brushed their teeth 3 to 4 times a day $(50 \%, P=0.039)$. A total of $77 \%$ $(P=0.037)$ had received information on how to brush their teeth and $46 \%(P=0.143)$ on what type of brush should be used; $51 \%(P<0.01)$ affirmed to use dental floss and $49 \%$ $(P=0.201)$ had received information on how to use it. Most adolescents visited the dentist during the previous year $(57 \%, P=0.312)$, and prevention was the most frequent reason $(50 \%, P=0.115)$. Gender was significantly associated with some variables, especially those of behavioral nature.

Conclusion: The findings of this survey demonstrate the importance of health strategies to positively influence adolescents who may serve as health multipliers.
\end{abstract}

Key words: Adolescent health; adolescent; oral health

\section{Resumo}

Objetivo: Verificar o conhecimento do adolescente de 10 a 19 anos de escolas públicas de Campina Grande, PB, em relação à saúde bucal.

Método: Foi realizado um estudo transversal com amostra probabilística de 679 adolescentes de escolas públicas de Campina Grande, PB. A coleta de dados foi feita por meio de questionário semiestruturado. Os dados foram estatisticamente analisados por testes Qui-Quadrado e Exato de Fischer, ao nível de significância de 5\%.

Resultados: A maioria recebeu informação sobre as doenças bucais $(88 \%, P=0,026)$, sendo o cirurgião-dentista $(66 \%, P=0,475)$ a fonte mais citada. Aproximadamente metade escovavam os dentes de 3 a 4 vezes por dia $(50,1 \%, P=0,039)$. Um percentual de $77 \%(P=0,037)$ recebeu informação sobre como escovar os dentes e $46 \%(P=0,143)$ sobre qual o tipo de escova que se deve usar; $51 \%(P<0,01)$ utiliza o fio dental e $49 \%(P=0,201)$ recebeu informações de como usá-lo. A maioria visitou o cirurgião-dentista no último ano $(57 \%, P=0,312)$ e a prevenção foi o motivo mais frequente $(50 \%, P=0,115)$. $O$ gênero apresentou associação significativa com algumas variáveis analisadas, em especial as comportamentais.

Conclusão: Estudos desta natureza embasam estratégias de saúde na tentativa de influenciar positivamente os adolescentes que atuarão em última análise como agentes multiplicadores de saúde.

Palavras-chave: Saúde do adolescente; adolescente; saúde bucal

\author{
Ana Flávia Granville-Garcia a \\ Lígia Virgínio Fernandes ${ }^{b}$ \\ Thiago Serpa Simões de Farias ${ }^{b}$ \\ Sérgio D'Avila a \\ Alessandro Leite Cavalcanti a \\ Valdenice Aparecida Menezes ${ }^{c}$
}

\begin{abstract}
a Graduate Program in Dentistry, Master's Degree Program in Dentistry, State University of Paraíba, Campina Grande, PB, Brazil

b Health Sciences and Biologic Center, State University of Paraíba, Campina Grande, PB, Brazil

c Graduate Program in Dentistry, Master's Degree Program in Pediatric Dentistry, University of Pernambuco, Camaragibe, PE, Brazil
\end{abstract}

\author{
Correspondence: \\ Ana Flávia Granville-Garcia \\ Rua Capitão João Alves de Lira 1325, apto 410 - \\ Bela Vista \\ Campina Grande, PB - Brasil \\ 58428-800 \\ E-mail: anaflaviagg@hotmail.com
}

Received: July 29, 2010

Accepted: September 1, 2010

Conflict of Interest Statement: The authors state that there are no financial and personal conflicts of interest that could have inappropriately influenced their work.

Copyright: (C) 2010 Granville-Garcia et al.; licensee EDIPUCRS. This is an Open Access article distributed under the terms of the Creative Commons AttributionNoncommercial-No Derivative Works 3.0 Unported License. 


\section{Introduction}

Adolescence refers to the period of life between 10 and 19 years old, according to the World Health Organization (WHO) criteria. During this phase of life, individuals are in constant biological, psychological and social development, which make them more vulnerable and in need of greater attention to health $(1,2)$.

Currently, there is an extension of this life stage as a result of early puberty, longer schooling period, and late entry into the labor market. Entering into a long period of intense growth and development, adolescents seeking health services are vary considerably and require specific actions (3). Adolescence is a stage in which general health is presented at its best, though it is a period of increased risk to oral health because of the greater independence with regard to the consumption of sugary foods and a certain revulsion regarding oral hygiene (1). Data published in the last national epidemiological survey conducted in Brazil (SB Brazil) revealed that about $14 \%$ of Brazilian adolescents have never been to the dentist. There are marked regional differences, whereas less than $6 \%$ of adolescents from the southern region reported ever having been to the dentist, while this value increased to almost $22 \%$ in the northeast region. Dental pain was one of the main reasons for going to the dentist reported by over $30 \%$ of the adolescents, while routine visits were reported by $34 \%$ of the subjects. Early tooth loss is severe and the need for some type of denture begins to emerge around the age of 15 to 19 years old (4). Health education has been considered an important strategy to promote community health through the development of personal skills for self care. Within this perspective and considering the weakness experienced in adolescence, it is necessary to develop educational measures on oral health in schools by means of programs capable of meeting the needs and characteristics of this portion of population (5-7).

The identification of adolescents as subjects with a proactive behavior in health decisions and the best persons to define their needs/priorities and expectations represents the possibility of having positive interactions with health professionals and their own environment. This would stimulate their interest on the search for and maintenance of healthier habits (8).

The relationship of adolescents with health services and their knowledge of oral health are not well explored in Brazil, although these themes are relevant and will help to define health actions focused on this population group. In light of this, the aim of this study was to evaluate the knowledge of adolescents attending public schools in a Brazilian city about oral health and attendance to dental services.

\section{Methods}

This study was approved by UEPB's Research Ethics Committee (CAAE 0179.0.133.000-08). This crosssectional, exploratory investigation included 10-19-year-old adolescents attending public schools in Campina Grande, which is the second most important city in the state of Paraiba, Brazil. The city is distant $130 \mathrm{~km}$ from the capital of Paraiba State and is located in the "Agreste" region of the State between the litoral and the hinterland, in the eastern region of the Borborema plateau. The city has a total area of $620.6 \mathrm{~km}^{2}$ and has an estimated population of 371,060 habitants (demographic density of $612 \mathrm{hab} / \mathrm{km}^{2}$ ) (9).

The study population comprised 11,773 students. A stratified sampling procedure was performed per health district and cluster (school). In each stratum was selected a certain number of schools and in each school was selected a random sample proportional to the number of students per school. A confidence interval of $95 \%$ was used and with $5 \%$ error. The following equation was used for sample calculation:

$$
\mathrm{n}=\frac{\mathrm{N} \cdot \mathrm{z}^{2} \cdot \mathrm{p} \cdot \mathrm{q}}{\mathrm{N}(\mathrm{n}-1)+\mathrm{z}^{2} \cdot \mathrm{p} \cdot \mathrm{q}}
$$

Where: $\mathrm{n}=$ corresponds to the sample size; $\mathrm{N}=$ corresponds to the population size; $\mathrm{Z}=$ chosen significance level in number of deviations (sigma); $\mathrm{d}=$ error margin and $\mathrm{p}=$ proportion of the characteristics sought in the universe, calculated as a percentage. For $\mathrm{p}$ and $\mathrm{q}$ values, $50 \%$ percentage was used (10). Thus, a sample of 668 students distributed proportionally among 6 health districts of Campina Grande was obtained.

Data collection was performed by two researchers from August to November 2008, using a semi-structured selfapplied questionnaire. The questions referred to information and source of information about dental diseases, frequency of brushing and sugar consumption, instructions on oral hygiene, frequency of visits to the dentist and reason for consultation. At baseline, the study purposes were explained to the eligible participants and informed consent forms were signed by the subjects or their parents/guardians. The reliability of responses was tested by the "face" validation method in $10 \%$ of research subjects. Using this method, the researcher asks the research subjects to make clear in their own words, what they understood about each question (11).

Data were organized using the SPSS (Statistical Package for the Social Sciences; SPSS Inc., Chicago, IL, USA) software and presented as descriptive (absolute and percentage distributions) and analytical statistics. The chi-square and Fisher's exact tests were used to assess the significance of associations at the $5 \%$ level of significance.

\section{Results}

Ten subjects refused to participate in the study and fill out the questionnaire. A total of 679 adolescents aged between 10 to 19 years were enrolled, being 311 (45.8\%) male and $368(54.2 \%)$ female. Table 1 shows that females received more information about oral health $(P=0.026)$, journals/ magazines being the only source of information with a significant difference between genders $(P=0.016)$. 
Table 1. Assessment of issues related to information about dental diseases according to gender of the adolescents (Campina Grande, PB, Brazil, 2009).

\begin{tabular}{|c|c|c|c|c|c|c|c|}
\hline \multirow{3}{*}{ Variable } & \multicolumn{4}{|c|}{ Gender } & \multirow{2}{*}{\multicolumn{2}{|c|}{ Total group }} & \multirow{3}{*}{$P$-value } \\
\hline & \multicolumn{2}{|c|}{ Male } & \multicolumn{2}{|c|}{ Female } & & & \\
\hline & $\mathrm{n}$ & $\%$ & $\mathrm{n}$ & $\%$ & $\mathrm{n}$ & $\%$ & \\
\hline \multicolumn{8}{|c|}{ - Did you receive information about how oral diseases occur? } \\
\hline $\begin{array}{l}\text { Yes } \\
\text { No } \\
\text { Total(1) }\end{array}$ & $\begin{array}{l}241 \\
70 \\
311\end{array}$ & $\begin{array}{l}77.5 \\
22.5 \\
100.0\end{array}$ & $\begin{array}{c}309 \\
58 \\
367\end{array}$ & $\begin{array}{c}84.2 \\
15.8 \\
100.0\end{array}$ & $\begin{array}{l}550 \\
128 \\
678\end{array}$ & $\begin{array}{l}81.1 \\
18.9 \\
100.0\end{array}$ & $P^{(2)}=0.026^{*}$ \\
\hline \multicolumn{8}{|c|}{ - Who informed you how dental diseases occur? } \\
\hline $\begin{array}{l}\text { Dentist } \\
\text { Yes } \\
\text { No } \\
\text { Doctor/health post }\end{array}$ & $\begin{array}{c}163 \\
78\end{array}$ & $\begin{array}{l}67.6 \\
32.4\end{array}$ & $\begin{array}{l}200 \\
109\end{array}$ & $\begin{array}{l}64.7 \\
35.3\end{array}$ & $\begin{array}{l}363 \\
187\end{array}$ & $\begin{array}{l}66.0 \\
34.0\end{array}$ & $P^{(2)}=0.475$ \\
\hline $\begin{array}{l}\text { Yes } \\
\text { No } \\
\text { Professor }\end{array}$ & $\begin{array}{c}94 \\
147\end{array}$ & $\begin{array}{l}39.0 \\
61.0\end{array}$ & $\begin{array}{l}123 \\
186\end{array}$ & $\begin{array}{l}39.8 \\
60.2\end{array}$ & $\begin{array}{l}217 \\
333\end{array}$ & $\begin{array}{l}39.5 \\
60.5\end{array}$ & $P^{(2)}=0.849$ \\
\hline $\begin{array}{l}\text { Yes } \\
\text { No } \\
\text { Friends }\end{array}$ & $\begin{array}{c}43 \\
198\end{array}$ & $\begin{array}{l}17.8 \\
82.2\end{array}$ & $\begin{array}{c}72 \\
237\end{array}$ & $\begin{array}{l}23.3 \\
76.7\end{array}$ & $\begin{array}{l}115 \\
435\end{array}$ & $\begin{array}{l}20.9 \\
79.1\end{array}$ & $P^{(2)}=0.118$ \\
\hline $\begin{array}{l}\text { Yes } \\
\text { No } \\
\text { Magazines }\end{array}$ & $\begin{array}{c}33 \\
208\end{array}$ & $\begin{array}{l}13.7 \\
86.3\end{array}$ & $\begin{array}{c}55 \\
254\end{array}$ & $\begin{array}{l}17.8 \\
82.2\end{array}$ & $\begin{array}{c}88 \\
462\end{array}$ & $\begin{array}{l}16.0 \\
84.0\end{array}$ & $P^{(2)}=0.192$ \\
\hline $\begin{array}{l}\text { Yes } \\
\text { No } \\
\text { Television }\end{array}$ & $\begin{array}{c}31 \\
210\end{array}$ & $\begin{array}{l}12.9 \\
87.1\end{array}$ & $\begin{array}{c}64 \\
245\end{array}$ & $\begin{array}{l}20.7 \\
79.3\end{array}$ & $\begin{array}{c}95 \\
455\end{array}$ & $\begin{array}{l}17.3 \\
82.7\end{array}$ & $P^{(2)}=0.016^{*}$ \\
\hline $\begin{array}{l}\text { Yes } \\
\text { No } \\
\text { Total }\end{array}$ & $\begin{array}{l}95 \\
146 \\
241\end{array}$ & $\begin{array}{l}39.4 \\
60.6 \\
100.0 \\
\end{array}$ & $\begin{array}{l}125 \\
184 \\
309 \\
\end{array}$ & $\begin{array}{c}40.5 \\
59.5 \\
100.0 \\
\end{array}$ & $\begin{array}{l}220 \\
330 \\
550\end{array}$ & $\begin{array}{l}40.0 \\
60.0 \\
100.0 \\
\end{array}$ & $P^{(2)}=0.806$ \\
\hline
\end{tabular}

* Significant difference at $5.0 \%$; (1) The difference between $n$ values was due to lack of information; (2) Through the chi-square test.

Table 2 shows that gender presented significant differences related to frequency of brushing $(P=0.039)$, sugar consumption $(P=0.018)$ and flossing $(P<0.001)$.

Table 2. Assessment of issues related to oral hygiene and sugar consumption, according to gender of the adolescents (Campina Grande, PB, Brazil, 2009).

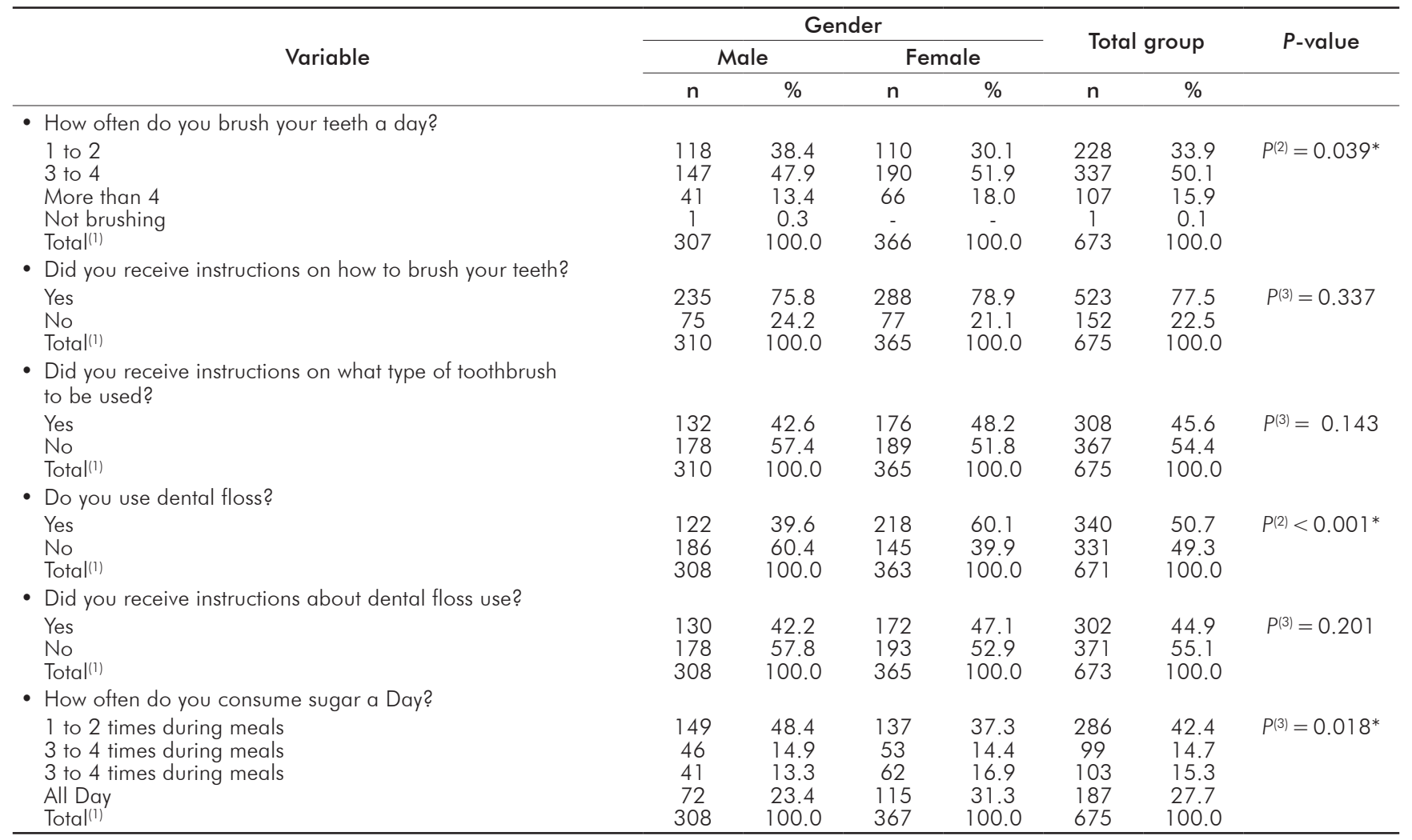

* Significant difference at $5.0 \%$; ${ }^{(1)}$ The difference between $\mathrm{n}$ values was due to lack of information; ${ }^{(2)}$ Using the Fisher Exact test; ${ }^{\left({ }^{3}\right)}$ Through the chi-square test. 
Table 3 shows that most adolescents said that there were situations when they spent more time brushing $(P=0.023)$, and the answer "when going out" was the justification that presented a significant difference between genders $(P=0.035)$.

Table 3. Assessment of issues related to tooth brushing according to gender (Campina Grande, PB, Brazil, 2009).

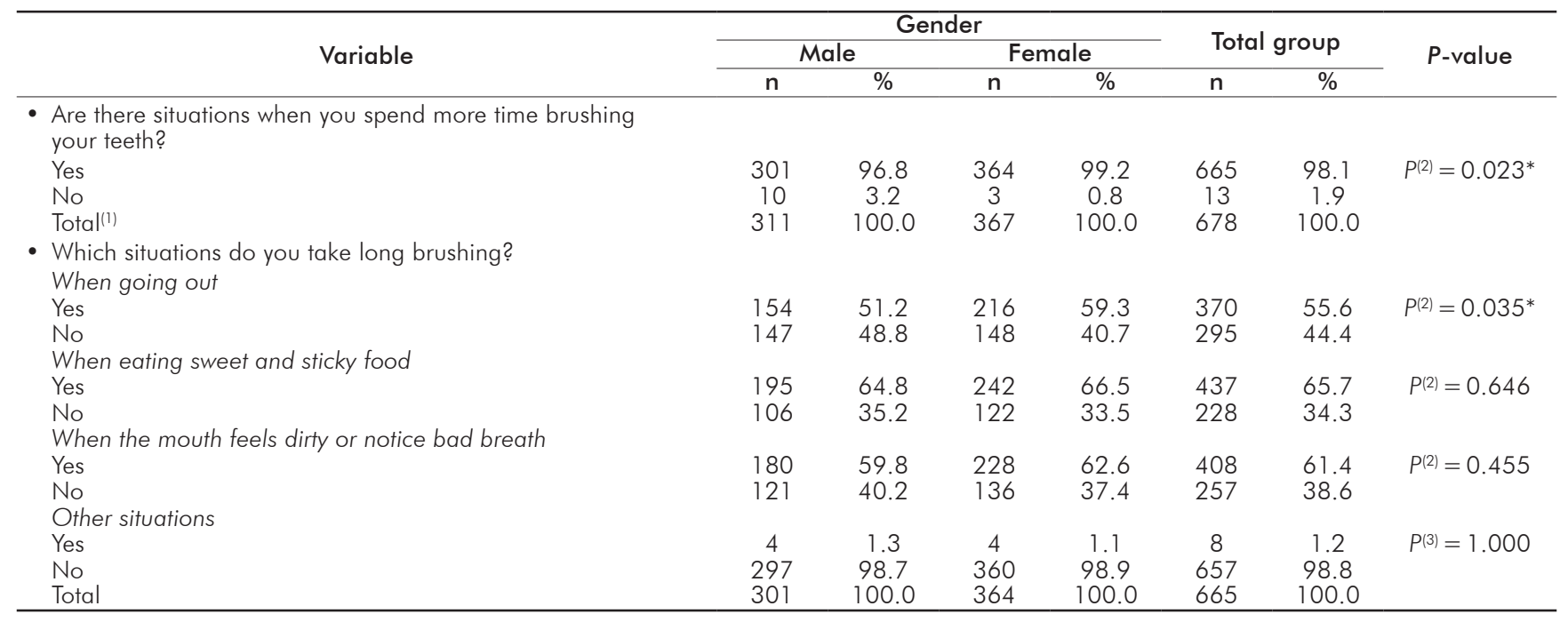

* Significant difference at $5.0 \%$; ${ }^{(1)}$ The difference between $\mathrm{n}$ values was due to lack of information; ${ }^{(2)}$ Using the Fisher Exact test; ${ }^{(3)}$ Through the chi-square test.

Table 4 highlights that $3.1 \%$ of adolescents had not been to the dentist $(P=0.244)$. The remaining questions (last visit to the dentist and the reason for consultation) showed no significant differences between genders.

Table 4. Assessment of issues related to visits to the dentist according to gender (Campina Grande, PB, Brazil, 2009).

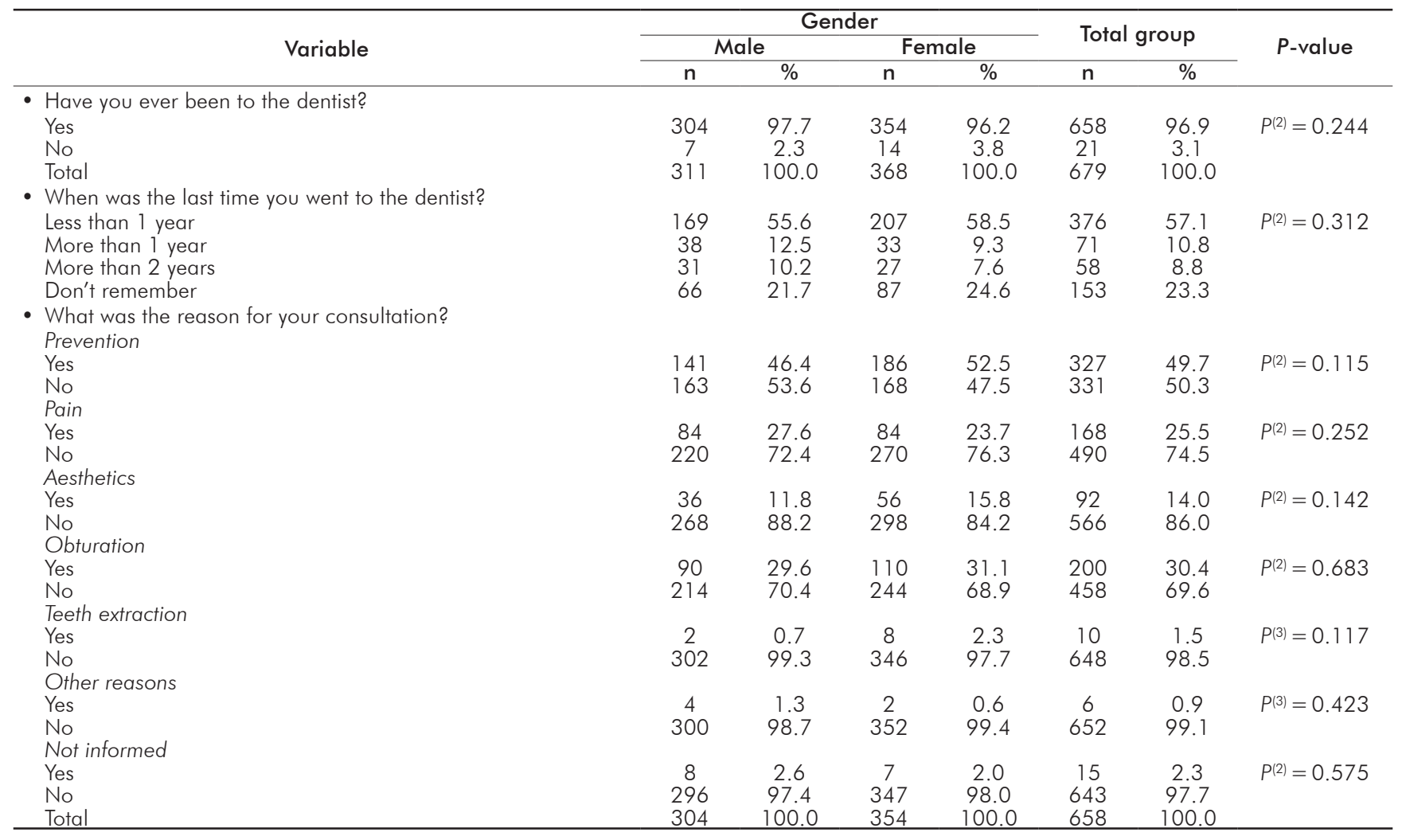

(1) The difference between $n$ values was due to lack of information; (2) Using the Fisher Exact test; (3) Through the chi-square test. 


\section{Discussion}

Education is a key strategy in the process of forming attitudes that promote and maintain health. Greater knowledge about health promotes changes in attitudes and motivation about healthy behaviors, increasing self-sufficiency to perform tasks, accelerating results of interventions to promote health (12). Highlighting the adolescent as an active subject in health decisions and as the greatest expert on their needs and desires represents the possibility of positive interactions with health professionals, facilitating construction of healthy education programs (13).

Despite the adoption of all criteria and methodological steps, some questionnaires were not filled in completely, causing limitations to this research. This is a common bias when using this instrument in data collection (14). Most adolescents received guidance on oral health $(81.1 \%)$, while females showed a greater number of positive responses. This findings is contrary to those of Ostberg et al. (15) and Santos et al. (16), who showed no significant differences between gender in this issue. Concerning information source, the dentist had a higher percentage $(66 \%)$, showing active participation of these professionals in the construction of oral health concepts (16). The second and third greatest sources of information were the doctor and television. The latter has a great influence on lifestyle and behavior as young Brazilians watch, on average, 3.5 hours of television per day (17). It is noteworthy that magazines were the only source that showed a significant difference between genders, possibly due to girls' interest in this type of media.

Young respondents, on the average, reported brushing 3 to 4 times a day $(50 \%)$, which is in accordance with other Brazilian studies $(7,16,18,19)$. This frequency is higher than that reported by international studies of this age group $(20,21)$, reinforcing the hypothesis of media influence in the country with advertisements on the need for oral hygiene three times a day. In addition, there may have been information bias, since individuals tend to report acceptable behavior even when they do not adopt them. On this issue, there was a significant difference between genders. The influence of gender on oral health behavior has been reported in the literature $(7,15,22)$.

Most had received instructions on how to brush their teeth (77\%), however, less than half had received information on the type of brush to be used (46\%) or on how to use dental floss (45\%). This fact deserves consideration, since professionals seem to direct its guidelines most for brushing methods. About $49 \%$ of subjects reported not using dental floss, a lower percentage than in other studies $(7,19)$. However, this percentage is significant when compared to the study by Knishkowy and Sgan-Cohen (23), who reported that only $7 \%$ of Israeli adolescents used it and $10 \%$ did not know about dental floss. There was greater use of dental floss among girls, as reported elsewhere (15). Free brush distribution to public schools, probably contributed to the overvaluation of the brush on oral hygiene. In addition, the dental floss is a more expensive project and not so widespread $(7,24)$. Sugar consumption was more frequent among girls (42\%). Otsberg et al. (22) reported no association between gender and sweets consumption. Although the consequences of this dietary habit was not addressed in this study, this group, which presented the largest number of tooth brushing and flossing sessions, seemed to be more aware of the relationship between sweet foods and dental caries.

The adolescents were asked if there was any situation that led them to spend more time on brushing, 98\% responded affirmatively, with a significant difference between genders. The reasons mentioned most frequently were "when eating sweets and sticky food" (66\%) "when feeling mouth with bad breath" (61) and "when going out" (56\%). Increased awareness of hygiene after eating as well as esthetics were reflected in this issue, and may be related to the advice given by the dentist and media influence, as well as the need for adolescents to have a good appearance (18). The use of dental services by Brazilian schoolchildren has not been investigated in depth. In this respect, when asked whether they had visited the dentist, only $3 \%$ of adolescents reported never seeing the dentist, a lower percentage than that reported for the Northeast in the last national survey (4). Campina Grande (PB) is a medium-sized city where access to dental services is easier. Moreover, what could have contributed to this result was the implementation of an oral health program by the government (Smile Brazil). Most adolescents (57\%) reported having visited the dentist in the last year, without association of this variable with gender. Other studies have described higher frequency of annual consultations by women $(7,15,25)$. The most cited reasons were prevention $(50 \%)$, filling $(30 \%)$ and pain $(25 \%)$. In contrast to the study by Freddo et al.(7) in which curative treatment was the most frequent cause for adolescents seeking treatment.

From the results of this study, it cannot be stated categorically that gender influences oral health behavior, as only some variables presented are significantly associated with gender. However, some reflections can be drawn from our findings, such as the importance of developing collective strategies based on the prevention of oral diseases in school, the training of teachers to control their risk factors, and continuing education by health professionals in order to form adolescent health multipliers that can disseminate knowledge of oral heath and diseases to their peers. The findings of this survey demonstrate the importance of health strategies in an attempt to positively influence adolescents who will ultimately serve as health multipliers. 


\section{References}

1. Garbin CAS, Garbin AJl, Moimaz SAS, Gonçalves PE. A saúde na percepção do adolescente. Rev Saúde Coletiva 2009;19: 227-38.

2. Francisco KMS, Sundefeld MLMM, Garbin JI, Garbin CAS. Técnica do grupo focal como método de avaliação do conhecimento de adolescentes sobre saúde bucal. Acta Scientiarum Health Sciences 2009;31:165-70.

3. Taquette SR, Vilhena ML, Silva MM, Vale MP. Conflitos éticos no atendimento à saúde de adolescentes. Cad Saúde Pública 2005; 21:1717-25

4. Brasil. Projeto SB Brasil. Condições de Saúde Bucal da População Brasileira 2002-2003. Brasília, DF: Ministério da Saúde; 2004. [Acessed on 2008 Jan 14]. Available at http://www.cfo.org.br/ download/pdf/relatorio_sb_brasil_2003.pdf.

5. Aerts D, Alves GG, La Salvia MW, Abegg C. Promoção de saúde: a convergência entre as propostas de vigilância da saúde e da escola cidadã. Cad Saúde Pública 2004; 20:1020-8.

6. Claro LBL, March C, Mascarenhas TM, Castro IAB, Rosa MLG. Adolescentes e suas relações com serviços de saúde: estudo transversal em escolares de Niterói. Cad Saúde Pública 2006;22:1565-74.

7. Freddo SL, Aerts DRGC, Abegg C, Davoglio R, Vieira PC, Monteiro L. Hábitos de higiene bucal e utilização de serviços odontológicos em escolares de uma cidade da Região Sul do Brasil. Cad Saúde Pública 2008;24:1991-2000.

8. Jeolás LS, Ferrari RAP. Oficinas de prevenção em um serviço de saúde para adolescentes: espaço de reflexão e de conhecimento compartilhado. Ciênc Saúde Coletiva 2003;8: 611-20.

9. Instituto Brasileiro de Geografia e Estatística. Cidades@. [Acessed on 2008 July 27]. Available at http://www.ibge.gov.br/cidadesat/ default.php.

10. Richardson RJ. Elementos da teoria de amostragem. In: Pesquisa social: métodos e técnicas. $3^{a}$ ed. São Paulo: Atlas; 1999.

11. Frankfort-Nachimias $C$, Nachimias D. Research methods in the social sciences. $4^{\text {th }}$ ed. London: Edward Arnold; 1992.

12. Frazão P, Marques D. Efetividade de programas de agentes comunitários na promoção da saúde bucal. Rev Saúde Pública 2009;43:463-71.
13. Brukiene V, Aleksejuniene J. An overview of oral health promotion in adolescents. Int J Paediatr Dent 2009;19:163-71.

14. Bonita R, Beaglehole R, Kjellstrom T. Basic Epidemiology. $2^{\text {nd }}$ ed. Geneva: World Health Organization; 2006.

15. Ostberg A, Halling A, Lindblad U. A gender perspective of selfperceived oral health in adolescents: associations with attitudes and behaviours. Community Dental Health 2001;18:110-6.

16. Santos NCN, Alves TDB, Freitas VS. A saúde bucal de adolescentes: aspectos de higiene, de cárie dentária e doença periodontal nas cidades de Recife, Pernambuco e Feira de Santana, Bahia. Ciênc Saúde Coletiva 2007;12:1155-66.

17. Linn S. Consuming Kids: The hostile takeover of childhood. New York: The New Press; 2004.

18. Flores EMTL, Drehmer TM. Conhecimentos, percepções, comportamentos e representações de saúde e doença bucal dos adolescentes de escolas públicas de dois bairros de Porto Alegre. Ciênc Saúde Coletiva 2003;8:743-52.

19. Davoglio RS. Fatores associados a hábitos de saúde bucal e utilização de serviços odontológicos entre adolescentes. Cad Saúde Pública 2009;25:655-67.

20. Al-Dlaigan YH, Shaw L, Smith AJ. Dental erosion in a group of British 14-year-old, school children. Part III: Influence of oral hygiene practices. Br Dent J 2002; 192:526-30.

21. Christensen LB, Petersen PE, Bhambal A. Oral health and oral health behaviour among 11-13-year-olds in Bhopal, India. Community Dental Health 2003;20:153-8.

22. Ostberg AL, Halling A, Lindblad U. Gender differences in knowledge, attitude, behavior and perceived oral health among adolescents. Acta Odontol Scand 1999;57:231-6.

23. Knishkowy B, Sagan-Cohen HD. Oral Health practices among adolescents: a study from family practice clinics in Israel. Int Adolesc Med Health 2005;17:99-104.

24. Noro LRA, Roncalli AG, Mendes Júnior FIR, Lima KC. Incidência de cárie em adolescentes em município do Nordeste brasileiro. Cad Saúde Pública 2009;25:783-90.

25. Honkala E, Kuusela S, Rimpelä A, Rimpelä M, Jokela J. Dental services between 1977 and 1995 by finish adolescents of different socioeconomic levels. Community Dent Oral Epidemiol 1997;25:385-90. 